- Short Communication

\title{
ENHANCEMENT OF HETEROTROPHIC ACTIVITIES IN POLLUTED WATER BY BACILLUS COAGULANS BW-25
}

\author{
MD. ABDUL KARIM ${ }^{1}$, REHENA NASRIN HAPPY, \\ MEHEDI-AL MASUM AND SIRAJUL HOQUE ${ }^{2}$ \\ Laboratory of Microbiology, Department of Botany, University of Dhaka, Dhaka-1000 and \\ ${ }^{2}$ Department of Soil, Water and Environment, University of Dhaka, Dhaka 1000, Bangladesh
}

Unsafe water is a global public health threat, placing persons at risk for a host of diarrhoeal and other diseases as well as chemical intoxication (Hughes and Koplan 2005). With the increase in interest in the microbial ecology of aquatic environments, it is important to have an understanding of the autochthonous micro flora. Since the bacteria are well known agents of mineralization and transformation of organic and inorganic matters in aquatic ecosystem, it was considered useful to determine the prevalence of some selected heterotrophic bacteria in the river. The objectives of the present study were, (i) isolation of indigenous bacteria possessing high metabolic activities, and (ii) improvement of the quality of water by enhancement of heterotrophic activities.

The area in and around Farashganj, Dhaka at the bank of the river Buriganga is a whole sell market of daily commodities. Residents around the river and people of the market take bath in the river and use the water for washing of vegetables and fruits were selected for the study site. Water samples were collected from surface area $(5 \mathrm{~cm}$ depth) with a sterile $2.0 \mathrm{~L}$ plastic bottle and were transferred to the laboratory within an hour of sampling. Temperature of water samples was measured at the time of sampling with the help of a mercury thermometer. The $\mathrm{pH}$ of water samples was measured by digital $\mathrm{pH}$ meter (Jenway 3310, UK) immediately after bringing the sample in the laboratory. Dissolved Oxygen (DO) of water sample was determined by DO meter (Jenway 970 $\mathrm{DO}_{2}, \mathrm{UK}$ ), while, conductivity was measured by conductivity meter (Hanna, MODEL-HI 9033). Total Dissolved Solids (TDS) was measured by TDS meter (Hanna, MODEL-HI 9034), and alkalinity was determined by titrimetric method.

One $\mathrm{ml}$ of sample water was transferred into $10 \mathrm{ml}$ of nutrient broth medium and incubated at $37^{\circ} \mathrm{C}$. After 48 hours of incubation, $0.1 \mathrm{ml}$ of bacterial culture from each tube was inoculated onto nutrient agar plates and incubated at $37^{\circ} \mathrm{C}$. Coagulated egg albumin medium, alkaline egg medium and skim milk agar were used for the screening of the proteolytic activity of the isolates (Wandersman et al. 1986). Considering fast growing and high proteolytic activity bacterial isolate BW-25 was selected for biotechnological application.

Five $\mathrm{ml}$ of bacterial cells suspension was used as inocula and it was inoculated into 250 $\mathrm{ml}$ treatment bottles (Schott, Duran, Germany). The glass bottles were incubated in a

1 Corresponding author: Email: makarim10@yahoo.com 
light condition in situ (in duplicate) at $32^{\circ} \mathrm{C}$ temperature for 15 days. Bacterial activities were evaluated by the changes of inorganic nutrient concentration into the water during incubation. Just after adding bacteria samples were taken as 0-day and it was continued until 15 days of incubation at 5 days interval. For chemical analysis, concentrations of inorganic nitrogen (DIN: ammonium, nitrate and nitrite) and phosphorus (DIP) in the experimental bottles were measured following the methods described in the previous paper (Karim et al. 2013). Important physiological and biochemical characteristics were studied for the identification of the selected bacterial isolate (Sneath et al. 1986 and SAB 1957).

The physico-chemical properties of water sample presented in Table 1 showed that in June, water temperature and $\mathrm{pH}$ were at $32^{\circ} \mathrm{C}$ and 6.7 , respectively, that indicate the favourable conditions for bacterial growth. But in case of DO, it was $0.76(\mathrm{mg} / \mathrm{l})$, COD was $18.26(\mathrm{mg} / \mathrm{l})$ and the BOD was consisted with water temperature as $0.59(\mathrm{mg} / \mathrm{l})$. The alkalinity, conductivity and TDS of sample water were $2.18(\mathrm{meq} / \mathrm{l}), 299.15(\mu \mathrm{s} / \mathrm{cm})$ and $145(\mathrm{mg} / \mathrm{l})$, respectively. In regards to proteolytic activities, BW-25 possessed high activities by clear zone into the medium and increased with incubation period.

Table 1. Chemical properties of the water sample collected from Buriganga river.

\begin{tabular}{cccccccccc}
\hline $\begin{array}{c}\text { Date of } \\
\text { Sampling tempera tempera } \\
\text { ture }\end{array}$ & $\begin{array}{c}\text { Air } \\
\text { ture }\end{array}$ & $\begin{array}{c}\text { Water } \\
(\mathrm{mg} / \mathrm{l})\end{array}$ & $\begin{array}{c}\mathrm{BOD} \\
(\mathrm{mg} / \mathrm{l})\end{array}$ & $\begin{array}{c}\mathrm{COD} \\
(\mathrm{mg} / \mathrm{l})\end{array}$ & $\begin{array}{c}\text { Alkalinity } \\
(\mathrm{meq} / \mathrm{l})\end{array}$ & $\begin{array}{c}\text { Conducti } \\
\text { vity } \\
(\mu \mathrm{s} / \mathrm{cm})\end{array}$ & $\begin{array}{c}\mathrm{TDS} \\
(\mathrm{mg} / \mathrm{l})\end{array}$ \\
\hline $\begin{array}{c}\text { June } \\
6,2011\end{array}$ & $31^{\circ} \mathrm{C}$ & $32^{\circ} \mathrm{C}$ & 6.70 & 0.76 & 0.59 & 18.26 & 2.18 & 299.15 & 145.00 \\
\hline
\end{tabular}

The isolate BW-25 showed positive results in gram reaction, catalase, oxidase, utilization of citrate, protease, $\mathrm{KOH}$, nitrate reduction, motility, hydrolysis of starch, gelatin and casein. However, it showed negative results in VP, MR, levan, phenayl alanine deaminase, tyrosine degradation, egg yolk lecithinase, egg yolk lipase, degradation of urea, propionate utilization, indole formation and dihydroxy acetone production. In case of hydrolysis of different carbohydrates the strain could produce acid from D-glucose with no gas, L-arabinose, D-xylose and D-mannitol. Considering morphological and physiological characteristics the isolate BW-25 was identified as Bacillus coagulans (Sneath et al. 1986 and SAB 1957).

One experiment was carried out using Bacillus coagulans BW-25 with water sample collected on June 6,2011 and incubated at $32^{\circ} \mathrm{C}$, the initial concentration of DIP in control was $0.06 \mathrm{mg} / \mathrm{l}$ that increased to $0.32 \mathrm{mg} / \mathrm{l}$ after adding bacteria (Fig. 1). Net releases of DIP in control were $0.13 \mathrm{mg} / \mathrm{l}$, while after adding bacteria it was increased to 
$0.26 \mathrm{mg} / \mathrm{l}$. In the result, net releases of DIN in control were $2.52 \mathrm{mg} / \mathrm{l}$ and it was increased to $14.82 \mathrm{mg} / \mathrm{l}$ with bacteria (Fig. 1). So, net releases of DIN after adding bacteria were $12.02 \mathrm{mg} / \mathrm{l}$ (Fig. 1).

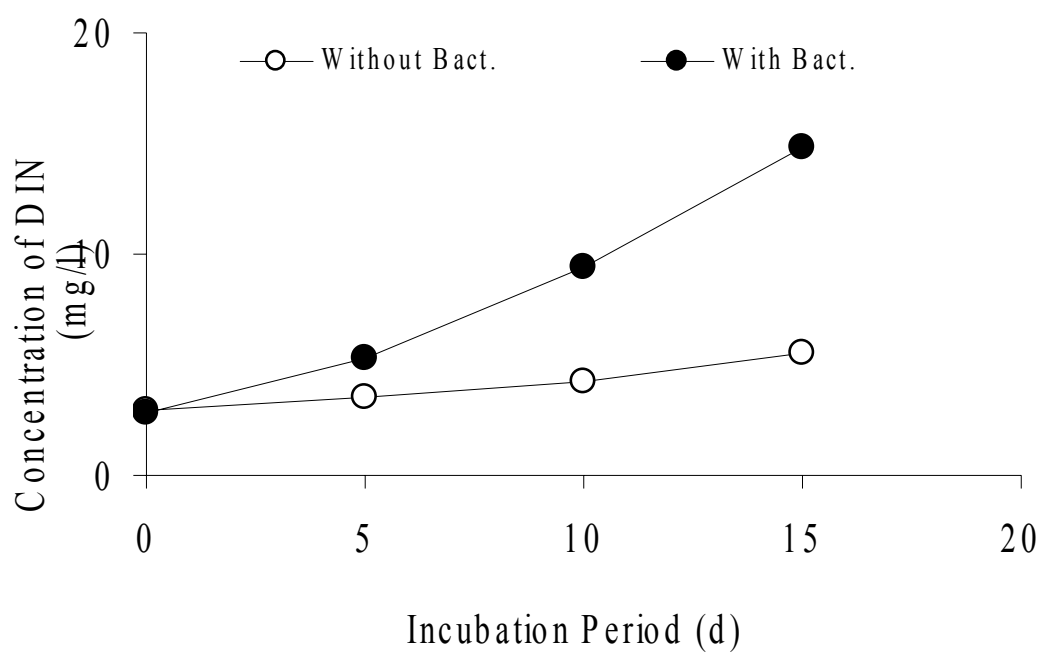

A

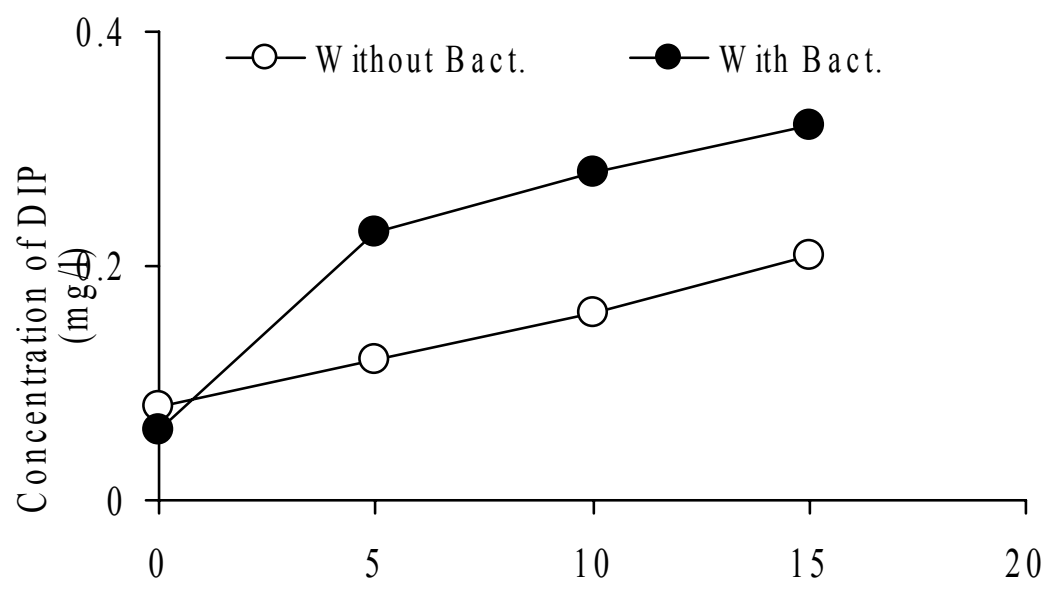

Incubation Period (d)

Fig. 1. Changes in concentration of dissolved inorganic nutrients by adding Bacillus coagulans $\mathrm{BW}-25$. A \& B, incubation temperature was $32^{\circ} \mathrm{C}$; sampling on June 6, 2011. Without Bacillus coagulans BW-25 (o) and with Bacillus coagulans BW-25 (•). 
Due to presence of oxygen demanding pollutants like organic wastes, there existed a rapid depletion of dissolved oxygen from this river water and thus creates problem for survival of fish. Even after treatment, domestic effluents are sources not only of chemical compounds but also of microorganisms that can be very active in the river, and play a fundamental role in the ecological functioning of the system (Garnier et al. 1992).

To stimulate heterotrophic activities in the specific limiting environmental conditions, addition of effective bacterial isolate which is capable of high proteolytic activities might be one useful way to control water pollution. Inducing the growth of particular bacteria could facilitate the biodegradation process of organic wastes or control fish pathogens even in large area of water (Rijn et al. 1995). In present study we tried to apply this method in a eutrophic ecosystem and monitored the effects of adding bacteria to enhance the heterotrophic activities. After adding Bacillus coagulans BW-25, net amounts and rates of DIN and DIP regeneration into water were markedly enhanced and it was about two folds higher than the control (Fig. 1). Probably it happened due to availability of labile organic matter in the water. It is necessary to conduct further study at the next stage regarding the removal of enhanced inorganic nutrients from the water.

\section{References}

Garnier, J., G. Billen and P. Servais. 1992. Physiological characteristics and ecological role of small and large sized bacteria in a polluted river (Seine River, France). Arch Hydrobiol. Ergebn. Limnol. 37: 83-94.

Hughes, J.M. and J.P. Koplan. 2005. Saving lives through global safe water. J. Emerg. Infect. Dis. 11(10): 1636-1637.

Karim, M.A., R.N. Happy, M. Al-Masum and S. Hoque. 2013. Bioremediation for improvement of polluted water by Bacillus licheniformis BW-37. Jahangirnagar University J. Biol. Sci. 2(1): 143-150.

Rijn, J.V., N. Fonarev and B. Berkowitz. 1995. Anaerobic treatment of indusive fish culture effluents: digestion of fish feed and release of volatile fatty acids. Aquaculture. 133: 920.

SAB (Society of American Bacteriologists). 1957. Manual of microbiological methods. McGrawHill Book Co. Inc. NY. pp. 1-315.

Sneath, P.H.A., N.S. Mair, M.E. Sharpe and J.G. Holt. (Eds.). 1986. Bergey's manual of systematic bacteriology $\left(9^{\text {th }}\right.$ Ed.). Vol. 2. The Williams and Wilkins Co., Baltimore, USA. pp. $965-$ 1594.

Wandersman, C.T. Andro and Y. Berthau. 1986. Extracellular proteases in Erwinia chrysanthemum. Gen. Microbiol. 132: 899-906. 